\title{
Quality of Life in the Time of Coronavirus from the Perspective of Social Work Karel Řezáč
}

DOI: $10.32725 /$ cetv.2021.011

\begin{abstract}
:
The time of the coronavirus crisis has virtually affected every aspect of our lives. Nevertheless, the effects of the pandemic and related measures are most often discussed in the public sphere in the context of health and economic aspects of social life. Social work, due to its complex nature, makes it possible to look at problems in a broader context, and therefore its perspective seems to be suitable for drawing attention to the all-round consequences of the pandemic and their impact on the quality of life. The aim of this theoretical study is to discuss and draw attention to the risks related to the quality of life that arise from the covid-19 epidemic and associated measures from the perspective of social work. To take into account the broader perspective of the view of quality of life, the concept of capability approach and the resulting basic human potentials was used to analyse the current situation.
\end{abstract}

Keywords: coronavirus, social work, quality of life, health, capability approach, potentiality, covid-19

\section{Introduction}

The ubiquity of the coronavirus crisis has virtually swallowed up 2020 since its beginning. By the end of January 2020,99\% of the population had already experienced the topic of coronavirus in the context of the Czech Republic. ${ }^{1}$ In a given year, the word coronavirus became the most searched word in the globally most used internet search engine. ${ }^{2}$ The coronavirus crisis has reached such proportions that its economic effects have been likened to the consequences of World War II, and the extent of its impact has affected not only global health systems, but virtually every aspect of human life. ${ }^{3}$ The response to this situation was the introduction of restrictive measures which inevitably accompany the pandemic. These measures, in the strictest form known as lockdown,

1 (c) MEDIAN, s.r.o., 'Koronavirus. Tisková zpráva', (online), available at: https://www.median.eu/cs/wp-content/uploads/2020/01/ MEDIAN_Tiskova_zprava_Koronavirus_20200131.pdf, cited 29 $9^{\text {th }}$ December 2020.

2 C Google, 'Rok 2020 ve vyhledávání', (online), available at: https://trends.google.com/trends/yis/2020/GLOBAL/, cited 29 ${ }^{\text {th }}$ December 2020.

3 Maria NICOLA et al., 'The socio-economic implications of the coronavirus pandemic (COVID-19): A review', International Journal of Surgery 78/2020, p. 185 
proved to be the key to preventing the spread of the epidemic. Its early use in Poland and the Czech Republic in mid-April served as an illustrative example of good practice in slowing the spread of the epidemic. ${ }^{4}$ Unfortunately, our patience with 'keeping the doors closed' was not enough to protect us from the crisis; it only slowed the onset of its gradation. At this time, health protection (perhaps rightly) gained a legitimate monopoly on intervention in all areas of human life. 'Health above all': this is how the philosophy of the coronavirus age could be characterised. But is this rhetoric and optics really universally valid? In the end, will not coping with a pandemic through harsh restrictions be a Pyrrhic victory of medicine with significant losses in other aspects of quality of life? Not even time may answer this question, as it will be very difficult and inaccurate to determine the extent to which anti-epidemic measures have affected the quality of life of all of us, and how inevitable these measures were to ensure a rapid return to standard life. This (sometimes frustrating) paradox is well known to all those working in the field of social work and helping professions. The effect of the worker's intervention often cannot be measured, and its significance for achieving change cannot be demonstrably interpreted. In addition, in the context of the traditional socio-ecological perspective of social work, we are used to working with a comprehensive view of the client and his difficulties. ${ }^{5}$ Even for this reason, social work appears to be a relevant area with a right to draw attention to the possible potential impacts of anti-epidemic measures in the context of a comprehensive view of quality of life. The aim of this theoretical study is to discuss and draw attention to the risks related to quality of life resulting from the epidemic of covid-19 and to associated measures from the perspective of social work.

\section{Methodology}

In order to fulfil the goal of this theoretical study, the method of a review study was chosen. There are basically two types of review studies. The first, more common type is usually part of an original research study, that is, a study that reports on one research project. The second, a more specific type, takes the form of a separate, comprehensive review study that maps research in the chosen area. However, in the professional literature we can meet a number of different types of review studies. Their designation, content focus, and stated numbers differ between individual authors. ${ }^{6}$ One of the types of review studies is the rapid review. This is a study that aims to respond to one problem in a relatively limited time. Based on the assignment, the author defines the criteria for searching the sources of key or current publications and describes and classifies the presented data of studies. Then he formulates his conclusions on the basis of the data. ${ }^{7}$ In the case of this method, the generalisation of conclusions and the interpretation of the findings which are tied to sources traced over a limited time are the restraints. On the other hand, the advantage is the possibility of reflecting the current topic in the immediate and relevant time. This advantage was the key when choosing this type of review study, as the 'coronavirus time', which forms the central context of the text, has been a current issue since 2020. Although it already includes a number of relevant studies, the area is not large enough to allow a standard systematic study requiring an average of two years of research. ${ }^{8}$ The search criteria and the choice of the texts of the re-

4 Shuliang O. CHENG and Shehryar KHAN, 'Europe's response to COVID-19 in March and April 2020 - A letter to the editor on "World Health Organization declares global emergency: A review of the 2019 novel coronavirus (COVID-19)'", International Journal of Surgery 78/2020, p. 3 .

5 Roman BALÁŽ, 'Komplexní posouzení: Spojení studia sociálních deviací se sociální praci', Sociální práce / Sociálna práca 6/2018, p. 28. Jiří MAREŠ, 'Přehledové studie: jejich typologie, funkce a způsob vytváření', Pedagogická orientace 4/2013, p. 429.

Ibid., p. 431.

8 Ibid. 
view study were also subject to this fact. First of all, standard research published in professional peer-reviewed journals was sought. However, due to the assumption that this was a more limited selection, research reports of the relevant institutions, official documents, and, occasionally, other sources relevant from the point of view of their origin were also accepted. Attention was always paid to compliance with the criteria of the relevance of the text according to the RADAR method. This method was published in 2013 primarily to help students orientate themselves in the world of electronic resources. Its universality allows and assumes use at all levels of text study. ${ }^{9}$ The texts for the study were searched with the help of online databases of scientific studies and Internet search engines on the basis of keywords combining the designations covid-19, etc., and the relevant potentials, respectively areas of quality of life. For the purposes of the study, those texts that most relevantly represented the knowledge about the effects of the pandemic in the given area were selected.

\section{Perspective of Social Work}

General definitions of social work represent the interpretation of common themes of social work which are a person - interaction - environment. ${ }^{10}$ The key to understanding the specific optics of social work is the concept that ensures the dynamics between these topics, respectively the subjects of social work, that is, social functioning. ${ }^{11}$ The use of the term social functioning goes beyond the boundaries of a certain theoretical school or a specific model of social work. The promotion of social functioning has also begun to be perceived as one of the main goals of social work as a specific profession. ${ }^{12}$ The term refers to a person's ability to manage the expectations of the environment of which he is a part. There is constant interaction between individuals and the environment. Normally, this interaction is in balance. If people do not manage the requirements of the environment sufficiently, the balance is fluctuating and a social problem arises. Such problems are then the subject of social work. ${ }^{13}$ This functionalist conception, or rather the essence and legitimacy of environmental expectations, is sometimes exposed, in the context of late modern society, to efforts to reform it more individually. These efforts include, for example, reflexive problem management ${ }^{14}$ or an extended perspective of interaction supplemented by the individual expectation dimension, that is, the free choice of a valuable life chosen from different ways of living. ${ }^{15}$ Despite these facts, the text is based on the original functionalist concept, as the mentioned need for individualisation is part of the interpretation of the concept of quality of life in the relevant part of the text.

An important part of the concept of the functionalist conception of social work is also the concept of life situation. The support of the balance between the client and his social environment is conditioned by focusing on a complex of diverse circumstances which, in total, represent the specific life situation of the client. These circumstances include both the characteristics of indivi-

9 Jane MANDALIOS, 'RADAR: An approach for helping students evaluate Internet sources', Journal of Information Science 4/2013, pp. 470-478.

10 Cf. Libor MUSIL and Daniela JAKLOVÁ STŘIHAVKOVÁ, 'Reflecting on a Common Core and the Variability of Social Work Definitions: "Theme and its Interpretations" by Foucault', Journal of Social Work Education 2/2020, pp. 384-393.

11 Cf. Pavel NAVRÁTIL and Libor MUSIL, 'Sociální práce s př́slušníky menšinových skupin', in: Sborník prací fakulty sociálních studií brněnské univerzity, Sociální studia č. 5, Brno: Fakulta sociálních studií, 2000, p. 118.

12 Pavel NAVRÁTIL, Reflexivní posouzení v sociální práci s rodinami, Brno: MUNI PRESS, 2014, p. 50.

13 Cf. NAVRÁTIL and MUSIL, 'Sociální..., p. 118.

14 Cf. NAVRÁTIL, Reflexivní..., p. 77.

15 Cf. Karel ŘEZÁČ, 'Koncepce očekávání jako komplexní evaluační nástroj v sociálních vědách', Sociální práce / Sociálna práca 6/2020, pp. 23-34. 
duals or groups and the characteristics of the environment in which these individuals and groups live. ${ }^{16}$ The social worker focuses on the partial dimensions of the client's situation. Depending on this focus, the approach of social workers varies. The subject of their intervention should be the situation of the client as a whole. The social worker should recognise all (medical, psychiatric, psychological, economic, qualification, spiritual, value and cultural, hygienic, relationship, and possible other) barriers operating in the process, that is, dealing with these barriers by the client, and think about the connections between them. It is this focus on the interdependence of the various circumstances of the client's life that cause the need for cooperation between workers even from other helping professions. Their specialisation allows them to penetrate into the depth and complexity of partial dimensions of life situations and at the same time prevents them from paying attention to their whole. The social worker should address this whole. However, when overcoming partial parts of the whole complex of obstacles in coping with a life situation, social workers and their clients cannot manage without cooperation with other specialists. Thus, an important part of the organisation of social work interventions is to ensure the continuity of goals, links, and activities of various helping professions. Poor coordination of the activities of various helping fields has unfortunate and often fatal consequences for the realisation of the goals of social work and for its clients. ${ }^{17}$ The term life situation refers to the multi-layered and unrepeatable factors that prevent or, conversely, facilitate the social functioning of an individual client or a specific category of clients. This term also defines the subject of the social worker's intervention. Reflection of the client's life situation (or category of clients) is the first and necessary step when choosing goals and methods of intervention that can contribute to the change of the client's life situation, strengthen his ability to cope with environmental requirements, and thus contribute to the process of restoring or maintaining his social functioning. ${ }^{18}$

The extent of the coronavirus crisis (and the restrictive measures mainly) is so widespread that it is difficult to imagine a person whose life situation would not be significantly affected. At the same time, the life situation is significantly related to the quality of life which was relatively recently defined in a discourse with a strong medical focus, that is, associated with and limited only to a certain sense - an illness and treatment. ${ }^{19}$ Despite the fact that many current authors interpret this concept from a broader perspective, which is presented in the upcoming chapter, in the context of the coronavirus crisis, the above-mentioned health and economic impacts on quality of life are employed the most. As illustrated by Behavio's quantitative research of April 2020, people's concerns about the coronavirus crisis most often included fear of illness, coverage of living costs, loss of employment, reduction of living standards, and securing repayments. ${ }^{20}$ This picture could have been observed throughout the year in the whole society. If metaphorically exaggerated, the subjective feeling caused by presented data on the increase of positively tested people and the increase of the planned deficit of the Czech state budget for the coming year (in hundreds of billions of Czech crowns) reached a viewership which is characteristic for weather forecasts or sports results mainly. With respect for the severity of the epidemic, one must be aware of the fact that, from a professional point of view, few of us could interpret this data correctly due to the frequent absence of a control sample, that is, similar records of the standard extent of ano-

16 Libor MUSIL, “Ráda bych Vám pomohla, ale..." Dilemata práce s klienty v organizacích, Brno: MZ, 2004, p. 15.

17 Ibid., p. 17.

18 Cf. NAVRÁTIL and MUSIL, 'Sociální..., p. 120.

19 Gary ROSENBERG and Gary HOLDEN, 'The Role of Social Work in Improving Quality of Life in the Community', Social Work in Health Care 25/1997, p. 13.

20 (c) Behavio Labs, s.r.o., 'Strach a koronavirus v Česku', (online), available at: https://behaviolabs.com/media/strach-a-koronavirus-vcesku/, cited $29^{\text {th }}$ December 2020. 
ther viral disease which is usually not subject to such an extensive testing. However, perceiving the impact of this crisis on the quality of life in terms of money and the number of patients only would be short-sighted and illusory.

\section{Quality of life}

Therefore, in order to take into account the broader perspective of the effects of the coronavirus crisis, it is necessary to define the concept of quality of life in a more specific and broader context. The view of man as a holistic being, taking into account aspects across biological, psychological, and sociological functions, has led medical science to a comprehensive view of the patient. It has stimulated interest in studying the quality of life of patients. ${ }^{21}$ The concept of quality of life is a very broad complex which includes physical and mental health, the relationship of the individual to his activities, society, environment, a complex of life aspects of subjective evaluation of well -being, and objective indicators (for example, the already mentioned life situation of a person). ${ }^{22}$ The concept of life situation is therefore mentioned by the World Health Organisation which uses this term to define the quality of life. According to this organisation, quality of life is defined as a subjective perception of one's own life situation in relation to culture, the value system, life goals, expectations, standards, and one's own interests. ${ }^{23}$ At the same time, this organisation formulated conditioning domains that form a complex of quality of life: (1) physical health, (2) psychological aspects, (3) degree of independence, (4) social relations, and (5) environment. ${ }^{24}$ Quality of life is sometimes also directly linked to the effects of illness, injury, medical treatment, or health poli$\mathrm{cy}^{25}$ It is also important to mention the fact that there is a direct proportion between healthcare and the quality of life of patients. Healthcare makes sense as long as it positively influences the quality of life of a patient. ${ }^{26}$

Within the definition of well-being, two main currents of interpretation are often mentioned. This is an objective and subjective well-being. While objective well-being is based on observable factors, such as wealth, health, or material possessions, subjective well-being means, in particular, mental well-being that is experienced psychologically. ${ }^{27}$ In the context of the capability approach theory, this duality can be identified in the interpretation of both Sen and Nussbaum. While Sen emphasises the principle of freedom of the person's choice and rather avoids a more specific categorisation of well-being, Nussbaum, albeit building her conception on Sen's concept, concretises well-being into ten measurable dimensions. ${ }^{28}$ The application of this approach into the model of functionalist social work potentially brings both the above-mentioned aspect of the necessary individualisation of social work and, at the same time, the possibility of better complexity when evaluating the quality of life. The task of a social worker in practice is to support and lead clients to the formulation and realisation of their own expectations in order to achieve a truly valuable

\footnotetext{
Sylvie SULKOVÁ et al., Hemodialýza, Praha: Maxdorf, 2000, p. 513.

Cf. Bohuslav HODAŇ and Tomáš DOHNAL, Rekreologie, Olomouc: Hanex, 2005.

World Health Organization, Measuring quality of life, Geneva: World Health Organization, 1997, p. 1.

Ibid., p. 4.

5 Cf. Ivan WILMOT and Bradley S. MARINO, 'Quality of Life and Psychosocial Care in Pediatric Heart Failure', in: Heart Failure in the Child and Young Adult, ed. John JEFFERIES, Anthony CHANG, Joseph ROSSANO, Robert SHADDY and Jeffrey TOWBIN, London: Academic press, 2018.

26 Eva DRAGOMIRECKÁ and Jitka BARTOŇOVÁ, WHOQOL-BREF, WHOQOL-100: Př́ručka pro uživatele české verze dotazníků kvality života Světové zdravotnické organizace, Praha: Psychiatrické centrum, 2006.

27 Luca D’ACCI, 'Measuring Well-Being and Progress', Social Indicators Research 1/2011, p. 49.

28 Cf. Karel ŘEZÁČ, 'Koncepce capability approach a její implikace posilující humanitu (nejen) sociální práce’, Caritas et Veritas 2/2019, pp. 41-44.
} 
life (according to the client's own determination). Specific categorised dimensions of the factors of the objective concept of well-being can serve as a base for a comprehensive assessment of the client's life situation which takes into account various contextual aspects of his situation. They can also be a starting point for evaluating the equality of different members or groups in society and form a criteria basis for declaring their rights. ${ }^{29}$ For the purposes of this text, the concept of objective well-being was chosen, as it seems more appropriate for the demonstration of the versatile effects of pandemic risks on the quality of life. Nevertheless, it should be noted that even the assessment of impacts in the context of subjective well-being would certainly be no less beneficial. However, it would probably require longer and deeper research based on retrospective interviews evaluating a longer time interval. At present, the conclusions of such a study would probably be very hypothetical and inaccurate.

A universal and multidisciplinary view of the quality of life with the potential for connection with social work was thus formulated within the concept of capability approach. This concept seeks to clarify the frequent confusion of value-based goals with the means to achieve these goals. Production and prosperity (and therefore health) are generally perceived as valuable, although they usually do not explicitly represent the role of value, but only the way to achieve it. The value itself is hidden in specific states of being and activities (functioning) which are referred to as potentialities (in the original capabilities) within this concept. ${ }^{30}$ Potentialities can be formulated in concrete form in ten basic areas. Their availability determines the value of quality of life. They are: (1) life; (2) physical health; (3) bodily integrity; (4) meaning, imagination, and thinking; (5) emotions; (6) practical thinking; (7) relationships - (a) social ties, (b) social conditions; (8) other species; (9) play; (10) control over one's environment - (a) political, (b) material. ${ }^{31}$

There is no hierarchy between potentialities or functioning, as we each build on different values and experience. ${ }^{32}$ For this reason, the concept of potentialities seems to be an appropriate normative framework for the purposes of this text and a reflection of the effects of the coronavirus crisis even outside the priority areas of health and material control. Research based on potentialities is characterised by sensitivity to personal, cultural, social, and political influences. In this way, it brings a number of new findings that allow not only monitoring of the current situation, but also the revealing of future trends. The approach based on potentialities emphasises the need to monitor resources, opportunities, and potential when dealing with adverse life situations of social work clients. ${ }^{33}$ In addition, the broad and varied view of the quality of life that this concept provides corresponds to the complex view of social work.

\section{Impacts of the Coronavirus Crisis in the Context of Potentialities}

The first potentiality, life, specifically represents the opportunity for man to live life to an ordinary length. The authors of a study published in the professional multidisciplinary journal PLOS ONE in September 2020 directly addressed the risk of the potential impact of a coronavirus pandem-

29 Ibid., p. 47.

30 Cf. Amartya SEN, 'Development as Capability Expansion', in: Readings in Human Development, ed. Sakiko FUKUDA-PARR and A. K. Shiva KUMAR, New Delhi and New York: Oxford University Press, 2003.

31 Martha NUSSBAUM, Creating Capabilties: The Human Development Approach, Cambridge, MA: Harvard University Press, 2011, pp. 33-34.

32 SEN, Development..., p. 43.

33 C Jitka NAVRÁTILOVÁ, 'Capability př́stup jako příklad kriticky reflektující praxe sociálních pracovníků’, (online), Sociální práce / Sociálna práca, available at: https://socialniprace.cz/capability-pristup-jako-priklad-kriticky-reflektujici-praxe-socialnich-pracovniku/, updated $11^{\text {th }}$ July 2018, cited $29^{\text {th }}$ December 2020. 
ic. Based on a model developed in the study that simulates several probable scenarios for the epidemic, the authors stated that even a mere $2 \%$ incidence of covid-19 in the country's population could cause a decrease in life expectancy in countries where this indicator of quality of life shows high numbers (an average of 80 years). The model takes into account a comparison of the total number of demonstrably infected persons with the number of registered deaths caused by covid-19 and the total number of deaths by other causes. It therefore reflects the general reduction in life expectancy of the general population. ${ }^{34}$ As mentioned above, the impact on physical health in the context of the coronavirus crisis is fairly evident and very often employed. It has already been highlighted by the World Health Organisation. According to it, in the case of some patients, there are health complications that can have lasting consequences for human health. ${ }^{35}$ However, in addition to the explicit impact of the pandemic on health, implicit impacts can also be expected. It is currently too early to estimate the ultimate impact on the health of all, including those who have not had covid-19. Relevant studies of a similar type are likely to emerge in the future. However, the Commonwealth Fund, which supports the quality and efficiency of the health system, already shows changes in outpatient care. On their basis, such effects can be expected. In April 2020, a data analysis revealed a decrease in outpatient medical examinations by almost $60 \%$. And although this number was no longer so dramatic in the further course of the pandemic, the number of standard examinations by many medical specialists is still significantly lower. ${ }^{36}$ At first sight, physical integrity is mainly related to overcoming the barriers to which people with physical disabilities are exposed rather than to the coronavirus crisis. In the concept of potentialities, though, its meaning is more general and includes the possibility of free mobility in the broadest sense. It is the restriction of travel that is explicitly linked to the pandemic and represents one of the most noticeable acts of interference in human freedom when protecting public health. Limitations related to restrictions on travel and free movement of persons during quarantine have had an impact on both international trade ${ }^{37}$ and the social and psychological aspects of quality of life, such as distress and the increased risk of mental illness. ${ }^{38}$ Similarly, one can look at the potentiality called meaning, imagination, and thinking which includes the opportunity to learn or practice one's faith. The predictions of some studies point to relevant concerns about the long-term effects of the absence of full-time teaching on the learning outcomes of pupils and students and a significant increase in the variability of skills and knowledge among individual pupils. ${ }^{39}$ Restrictions on religion as a result of the coronavirus crisis have reached such proportions that, for example, the International Religious Freedom Alliance has drafted a joint statement highlighting frequent violations of religious freedoms due to overly restrictive measures restricting freedom of religion and the expression of one's faith, such as the ban on religious services, practising the faith, and the realisation of religious education. ${ }^{40}$ The area of emotions can also be considered as severely

34 Cf. Guillaume MAROIS, Raya MUTTARAK and Sergei SCHERBOV, 'Assessing the potential impact of COVID-19 on life expectancy', PLOS ONE 9/2020, p. 23.

35 (c) World Health Organization, 'What we know about Long-term effects of COVID-19', (online), available at: https://www.who.int/ docs/default-source/coronaviruse/risk-comms-updates/update-36-long-term-symptoms.pdf, updated $9^{\text {th }}$ September 2020 , cited $29^{\text {th }}$ December 2020.

36 Cf. () Ateev MEHROTRA et al., 'The Impact of COVID-19 on Outpatient Visits in 2020: Visits Remained Stable, Despite a Late Surge in Cases', (online), available at: https://doi.org/10.26099/bvhf-e411, updated 22 ${ }^{\text {nd }}$ February 2021, cited 29 $9^{\text {th }}$ March 2021.

37 Cf. @ Bengt SÖDERLUND, 'The impact of travel restrictions on trade during the COVID-19 pandemic', (online), available at: https:// voxeu.org/article/impact-travel-restrictions-trade-during-covid-19, updated $4^{\text {th }}$ November 2020, cited $29^{\text {th }}$ December 2020.

38 Cf. Isaac Yen-Hao CHU, Prima ALAM, Heidi J. LARSON and Leesa LIN, 'Social consequences of mass quarantine during epidemics: a systematic review with implications for the COVID-19 response', Journal of Travel Medicine 7/2020, p. 192.

39 Megan KUHFELD, James SOLAND, Beth TARASAWA et al., 'Projecting the Potential Impact of COVID-19 School Closures on Academic Achievement', Educational Researcher 8/2020, p. 562.

40 Cf. () International Religious Freedom Alliance, 'COVID-19 and Religious Minorities Pandemic Statement', (online), available at: 
affected by the coronavirus crisis. In addition to the already mentioned fear, which can even be described as a symbol of coronavirus time ${ }^{41}$ it is appropriate to mention, for example, the effects of restrictions on rememberance activities. Becoming a survivor in the coronavirus period is a challenge at every stage of the funeral process, from planning to going through the funeral ritual and obtaining a tombstone. In addition, long-term negative effects resulting from insufficient support for the process of managing the traumas associated with the sudden departure of loved ones can be expected. ${ }^{42}$ The potentiality called practical thinking means the possibility of realising individual life plans through guaranteed freedom. Restrictions on freedom and the adaptation of one's own plans virtually run through all potentialities. Despite this, an interpretation of this potentiality unaffected by the coronavirus crisis still could be found. According to some authors, practical thinking is a specific potential that deserves special attention, as it is an activating factor of life according to one's own value determination. ${ }^{43}$ On the other hand, in the context of the given potentiality, we can also consider the fact that restrictions affecting the accessibility of other potentialities de facto cause restrictions in terms of practical thinking. The realisation of free choice does not reach such a wide range of potential options, thereby these choices are degraded. The potentiality of relationships involves two levels. There are relationships in the sense of the possibility to participate in social interactions and relationships as an opportunity to receive recognition from others. Without question, considering both levels, social relations are also adversely affected by the coronavirus crisis due to quarantine. According to an extensive global study of social impacts, quarantine has led to huge declines in the perception of quality of life in social activities within the family (58\% decrease) and in friendly and neighbourly relations ( $44.9 \%$ decrease). ${ }^{44}$ Of course, social distance brings a number of risks. Its danger lies in the growing risk of social exclusion, growing depersonalisation, individualism, and the loss of the sense of belonging to the community. Furthermore, learning and development may be adversely affected due to the disruption of social ties. Reducing socialisation means reducing one of the most basic human needs. ${ }^{45}$ Although, for many people, quarantine was an opportunity to deepen relationships with other species, that is, pets, and spending time in nature was often the only available enriching environment for spending time, even within the area of this potentiality one can assume possible adverse effects. For example, in the case of people who are used to contact with animals outside their home (at relatives' or acquaintances' homes, in zoos, etc.). The potentiality called play can be interpreted as an opportunity to laugh, rejoice, and enjoy recreational activities. According to the already mentioned research, the decrease in human entertainment due to the pandemic ranged between $44.9 \%$ and $46.7 \% .{ }^{46}$ People have drastically fewer opportunities to visit restaurants, cafes, sports venues, and virtually all places where one can spend free time. The last potentiality called control over one's environment involves two levels. The material (economic) level in the context

https://www.state.gov/covid-19-and-religious-minorities-pandemic-statement/, updated $20^{\text {th }}$ August 2020, cited $29^{\text {th }}$ December 2020.

41 Cf. Behavio Labs, s.r.o., 'Strach...'

42 (c) Alexander BURRELL and Lucy E. SELMAN, 'How do Funeral Practices Impact Bereaved Relatives' Mental Health, Grief and Bereavement? A Mixed Methods Review with Implications for COVID-19', (online), available at: https://journals.sagepub.com/doi/ pdf/10.1177/0030222820941296, pp. 35-36, cited 29 $9^{\text {th }}$ December 2020.

43 Cf. Annie AUSTIN, 'Turning Capabilities into Functionings: Practical Reason as an Activation Factor', Journal of Human Development and Capabilities 1/2018, pp. 24-37.

44 Achraf AMMAR, Hamdi CHTOUROU, Omar BOUKHRIS et al., 'COVID-19 Home Confinement Negatively Impacts Social Participation and Life Satisfaction: A Worldwide Multicenter Study', International Journal of Environmental Research and Public Health 1/2020, pp. 13-14.

45 Kevin SIKALI, 'The dangers of social distancing: How COVID-19 can reshape our social experience', Journal of Community Psychology 8/2020, p. 2435.

46 AMMAR et al., 'COVID-19..., p. 13. 
of the coronavirus crisis is currently perceived as crucial. The risks associated with the loss of economic productivity, the decline of most industries and services, and also the more individual level associated with expectations of rising unemployment and the economic crisis in general are being discussed. ${ }^{47}$ Political control, in turn, has naturally been weakened by the introduction of national crisis management in the form of a state of emergency. ${ }^{48}$

Thus, we can say that the effects of the coronavirus crisis can be observed across all aspects of the quality of human life in its individual potentialities. Based on this fact, it can be stated that the pandemic has adversely affected the life situation of most people in society. It also may happen that some of them become dependent on the support of social work in order to deal with the new form of their situation. On the other hand, positive effects on the quality of life can also be identified. Such findings currently form a rather marginal or neglected part of the consequences of the pandemic, but in terms of balance, it is appropriate to mention these benefits.

The often-mentioned positive impact of the covid-19 pandemic mainly regards changes in the environment. One can observe not only the improvement of air quality and climate, but also the better condition of water and life of aquatic fauna. In some watercourses, water quality improvements of up to $50 \%$ have been recorded, and, at the same time, the return of many species of aquatic animals to their original habitats has been observed. The closure of factories and commercial operations has reduced the level of pollution around the world. The same situation has applied to traffic restrictions. ${ }^{49}$ From the point of view of potentialities, new opportunities can be stated in terms of the potentiality called other species or directly health, as it can be assumed that these changes will, in some respects, lead to a general improvement of the health status of the population as well. In the context of the potentiality called meaning, imagination, and thinking, and hence the potentiality called practical thinking, one can find a benefit in digital innovation which, despite the pre-existing possibilities, was triggered by the pandemic of covid-19. In addition, this digital transformation has provided more attention to children's education itself and to the previously rarely used tools for the digital improvement of teaching. ${ }^{50}$ For workers, an innovative view of home office is gaining prominence. It did not have so much attention before. Now, this form of work is gaining the form of a strategic plan in order to make it more feasible. ${ }^{51}$ In another study with a total of 1,519 respondents aged 18 to 91 , the possibility of working from home was the factor which led to a positive perception of the effects of the pandemic and restrictive measures. In addition to the home office, emphasis was placed on greater opportunities for rest and, paradoxically, more intensive social contact with loved ones. ${ }^{52}$ Another study even offers a direct listing of a total of 29 positive effects of the covid-19 pandemic, including greater awareness of the importance of close social relations, global alliances and national cohesion, the prospect of future health system consolidation, new business opportunities, crime reduction, etc. ${ }^{53}$ As with adverse

47 Cf. Amory MARTIN, Maryia MARKHVIDA, Stéphane HALLEGATTE, Brian WALSH, 'Socio-Economic Impacts of COVID-19 on Household Consumption and Poverty', Economics of Disasters and Climate Change 4/2020, pp. 471-472.

48 Resolution of the Government of the Czech Republic of $30^{\text {th }}$ September 2020, No. 957.

49 Cf. Ibrahim KHAN, Dawood SHAH and Sayed Suliman SHAH, 'COVID-19 pandemic and its positive impacts on environment: an updated review', International Journal of Environmental Science and Technology 2/2020, pp. 521-530.

50 Cf. Netta IIVARI, Sumita SHARMA and Leena VENTÄ-OLKKONEN, 'Digital transformation of everyday life - How COVID-19 pandemic transformed the basic education of the young generation and why information management research should care?', International Journal of Information Management 6/2020, p. 5.

51 Lina VYAS and Nantapong BUTAKHIEO, 'The impact of working from home during COVID-19 on work and life domains: an exploratory study on Hong Kong', Policy Design and Practice 1/2021, pp. 59-76.

52 Mandy GIJZEN et al., 'The Bittersweet Effects of COVID-19 on Mental Health: Results of an Online Survey among a Sample of the Dutch Population Five Weeks after Relaxation of Lockdown Restrictions', International Journal of Environmental Research and Public Health 23/2020, pp. 6-9.

53 Kankanige KARUNATHILAKE, 'Positive and negative impacts of COVID-19, an analysis with special reference to challenges on the 
effects, there are also all-round positive effects that can be a potential source of finding ways to live a valuable life.

\section{Future challenges for social work}

Predictions of future developments may sometimes be inaccurate, but they are the key to the preparation for the change that will undoubtedly occur after the coronavirus pandemic. Using the optics of the capability approach, the attention of social workers is not focused on monitoring the specifics of the client's environment only. The concept is also a great inspiration, as it focuses the attention on resources and potentialities that are essential for improving the social functioning of social work clients. An analytical view which uses the potentialities to assess human functioning and well-being gives social workers a tool that allows them to assess the client's life situation in situations that are associated with a number of uncertainties for social workers. From the point of view of social work, potentialities bring a large number of stimuli for the area of assessment, that is, something that is crucially important for a social worker and has a key position in his activity. ${ }^{54}$ In view of the above analysis of the effects of the coronavirus pandemic and related anti-epidemic measures, several scenarios can be expected that will characterise the near future of social work practice.

The first expected dimension is related to the assumption that the significant and ubiquitous effects of the coronavirus crisis on quality of life will lead to a general increase in social work clients. As a result, the risk of long-term health, economic, social, and psychological consequences can easily mean more people in an unfavourable life situation. In order to address such a situation, these people will seek the help of social workers from various fields of social work.

The second dimension of the effects of coronavirus time creates greater demands on the attention of social workers, especially within the comprehensive assessment of the living situation of social work clients. ${ }^{55}$ Due to the complexity of the crisis, social workers will in the future (at least for some time) face the effects of the coronavirus in various forms and contexts affecting the quality of life and living conditions of social work clients. Social problems will thus acquire a new dimension or directly a specific type of problems. These issues could reach such dimensions that they would become a separate topic and a specific area requiring the intervention of social work.

Based on the two previous dimensions, a third potential future scenario can be deduced, respectively a challenge for social work and society as a whole. If there is an increase in clients and the crystallisation of a new area of social work dealing with the effects of coronavirus in the future, it will be appropriate to set up specialised services and social programmes addressing social issues with a specific key feature. This attribute covers problems emerging due to the coronavirus crisis and its impacts.

At the same time, however, new threats also bring new opportunities. The versatility of human well-being allows one to choose sources of support from a wide range of options. So, it is desirable to be aware of and seek resources, in order to support positive change in a difficult life situation, among the positive effects of a pandemic as well. Hypothetically, it can be assumed that the conscious fragility of humanity, which we have been confronted with due to the pandemic, will contribute to the perceived higher value of things. It includes those things which one has been deprived of for a (hopefully) limited time. An even more important source can be, for example,

supply chain in South Asian countries', Journal of Social and Economic Development 1/2020, p. 146.

54 @ NAVRÁTILOVÁ, 'Capability....'

55 Cf. BALÁŽ, 'Komplexní...’’ p. 28. 
the time gained through a digitally improved and thus more effective job or school. And it can be used for a soothing walk in nature which is healing itself.

\title{
Conclusion
}

The coronavirus crisis naturally brings widely discussed health and economic consequences with the risk of long-term effects. In the strong emphasis on these consequences, however, the broader context of the effects of the pandemic is somehow downgraded. The perspective of social work, with its characteristic complexity, must make sure that even these aspects are given space in the public discourse. At the same time, it must make sure that the positive effects of the difficult experience are not forgotten. The concept of potentialities demonstrates that the coronavirus pandemic brings versatile risks as well as new opportunities for different dimensions and quality of life indicators. These facts are even more important for social workers, because they can influence it (by giving it several directions), and, to some extent, transform the form of social work practice as a profession in the future. It is therefore appropriate to call for vigilance, preparation, and planning of the response to complex social changes offering the (un)favourable potential of the coronavirus crisis. The past year of 2020 has enabled us to expand our professional skills. We have gained experience in an often completely new form of providing social assistance to those who need it. Let us use this potential to develop and plan a strategy which can help one to deal with the expected effects of the crisis. The announced future challenges for social work will require the consolidation of the values and goals of social work. This process has to be done in order to successfully overcome these challenges and successfully correct the coronavirus-induced imbalances in society. We should prepare ourselves together and gradually begin to build a practice that will not only bring us back to an original form of social life, but will also ensure that our efforts to cope with the expected changes can lead to our strengthening and self-cultivation.

\author{
Contact \\ Dr Karel Řezáč \\ University of West Bohemia in Pilsen \\ Faculty of Philosophy \\ Department of Sociology \\ Sedláčkova 15, 30100 Plzeň \\ rezack@kss.zcu.cz
}

